Anna M. Barańska ${ }^{1}$

ORCID: 0000-0002-6426-4115

Konrad Eckes ${ }^{2}$

ORCID: $\underline{0000-0002-0220-2277}$

\title{
SPATIAL RELATIONS BETWEEN THE FIELD OF PLAY FOR TEAM SPORTS AND THE TARGET. CASE STUDY: FOOTBALL
}

\author{
${ }^{1}$ AGH University of Science and Technology, Faculty of Mining Surveying and Environmental Engineering, Krakow, Poland \\ 2 The State University of Technology and Economics, Jaroslaw, Poland
}

Keywords: football geometry, indicator of opportunity, equal opportunity isolines

\begin{abstract}
The objective of this research paper is to establish the relationship between a randomly selected point of the field of play and the target. The analysis has been based on an exemplary pitch and the rules of football. A decision to desist from the field gain and to take a shot must take into account the relationship between the possible angle of dispersion and the angle at which the goal can be seen. The latter one (denoted as $\gamma$ ) has been devoted special attention here. Then, we have paid special attention to the fact that the view of the goal decreases as the player moves away from the longitudinal axis of the pitch. By turning the direction of the goal line $b$ to the direction that is perpendicular to the line of shot, we obtain a decreased projection of the goal $t$. The indicators such as angle $\gamma$, projection $t$ and its quotient version $N$ aptly define various spatial situations that occur in the field of play. However, in order to add better illustration to the assessment, another indicator $(V)$ has been proposed. It treats the changing view of the goal as an "aiming target" observed from varying distances. The comparability of the opportunities has also been demonstrated in the form of circle-shaped isolines, based on the chord of the goal. The performed analyses have legitimised the standard rule and aim of football which involves favourable field gain along the wings and finally crossing the ball into the middle field.
\end{abstract}

\section{RELACJE PRZESTRZENNE POMIĘDZY POLEM GRY ZESPOLOWEJ A OBIEKTEM CELU NA PRZYKŁADZIE PILKI NOŻNEJ}

Słowa kluczowe: geometria piłki nożnej, wskaźnik szansy, izolinie równych szans

\begin{abstract}
Abstrakt
Celem artykułu jest ustalenie związku między losowo wybranym punktem pola gry a celem. Analiza została oparta na przykładzie boiska i zasadach futbolu. Decyzja o odstąpieniu od zdobywania pola i oddaniu strzału musi uwzględniać związek między możliwym kątem rozproszenia a kątem, pod jakim można zobaczyć bramkę. Temu ostatniemu (oznaczonemu przez $\gamma$ ) została poświęcona szczególna uwaga. Zwrócono też uwagę na fakt, że widok bramki zmniejsza się w miarę oddalania się gracza od osi podłużnej boiska. Obracając kierunek linii bramkowej $(b)$ w kierunku prostopadłym do linii strzału, uzyskujemy zmniejszony rzut bramki $(t)$. Wskaźniki, takie jak kąt $\gamma$, rzut $t$ i jego ilorazowa wersja $N$ trafnie określają różne sytuacje przestrzenne występujące na polu gry. Jednak w celu lepszego zilustrowania oceny zaproponowano kolejny wskaźnik ( $V$ ). Uwzględnia on zmieniający się widok bramki jako „cel” obserwowany z różnych odległości. Porównywalność możliwości została również wykazana w postaci izolinii w kształcie koła, opartych na cięciwie bramki. Przeprowadzone analizy potwierdziły doświadczalną zasadę i cel piłki nożnej, który polega na korzystnym zdobywaniu pola wzdłuż skrzydeł i ostatecznie przerzuceniu piłki na środkowe pole.
\end{abstract}




\section{INTRODUCTION}

The problem of spatial relations between a randomly selected point of the field of play and the goal occurs in several team sports: in football, handball, hockey, and in water polo. The above-mentioned sport disciplines have the field of play and two vertical goals defined. These fields are characterised by double symmetry relative to the two axes of symmetry of the pitch: the longitudinal axis and the half-way line of the rectangular field of play. All of these games have the same aim: to place a ball or a puck in the opposing team's goal.
Among the abundant and diverse rules, guidelines and strategies, these spatial similarities and the aims of the games remain common features.

Let us try to determine the relationship between a randomly selected point of the field of play and the target. Our analysis shall comprise of an exemplary pitch and the rules of football. The football pitch has the largest dimensions, therefore, the results of the analysis may be the most distinct.

The football pitch must be a rectangle (but not a square). Permissible dimensions of the pitch fall within the following ranges (Eckes, 2018):

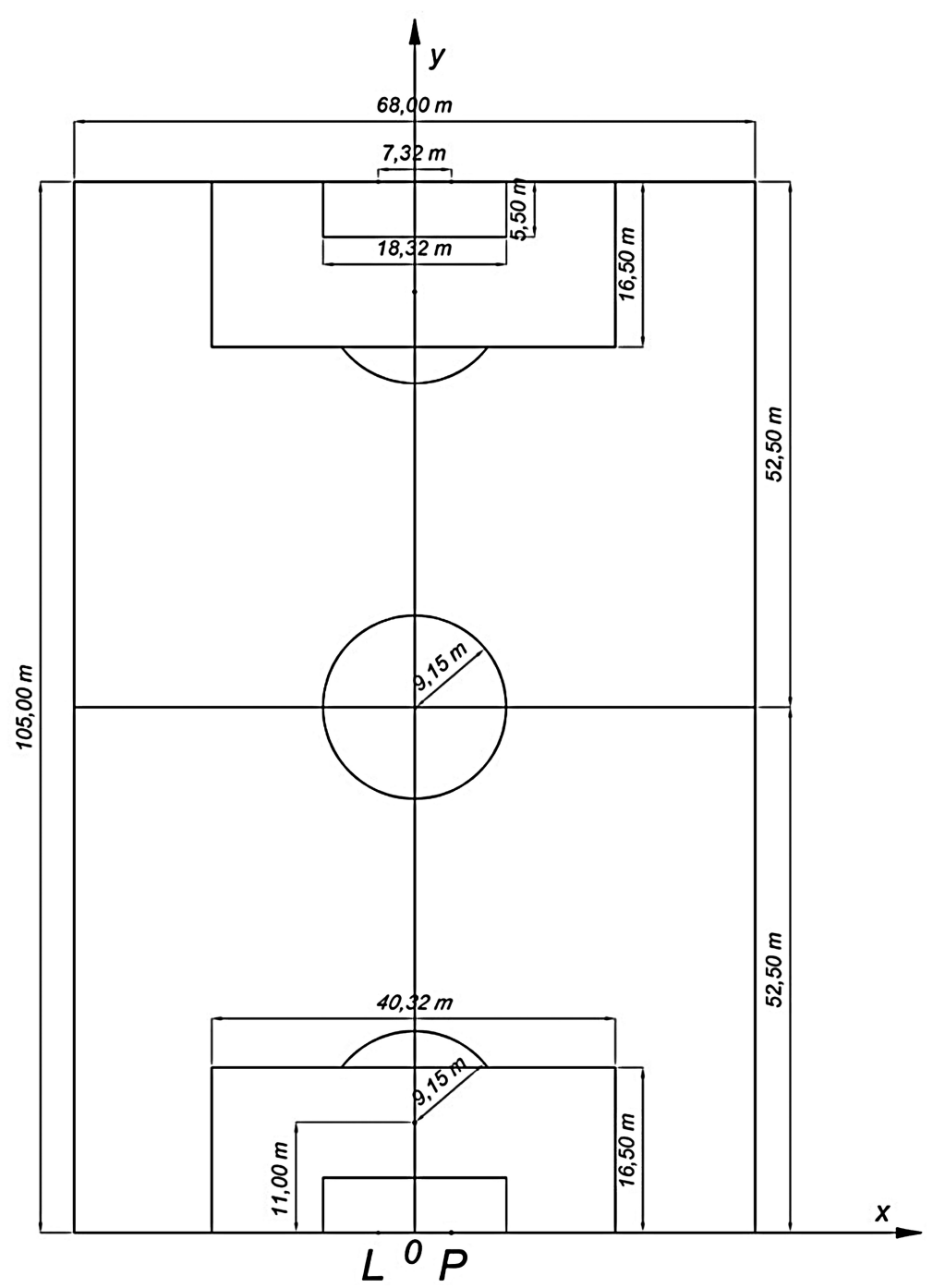

Fig. 1. Normalised dimensions of a football pitch applicable to newly erected facilities in force since 2008 - geometry of lines, areas, arcs and goals and the coordinate system adopted for the analyses

Rys. 1. Znormalizowane wymiary boiska do piłki nożnej obowiązujące dla obiektów nowo powstających od roku 2008 - geometria linii, pól, łuków i bramek oraz przyjęty do analiz układ współrzędnych 
- a length of 90-120 m and a width of 45-90 m for the facilities erected before 2008,

- for international matches, only the facilities erected before 2008 whose dimensions are tightly constrained to the goal lines having the length of $100-110 \mathrm{~m}$ and the touch lines having the length of $64-75 \mathrm{~m}$ are allowed as venues,

- since March 2008, strictly defined dimensions of $105 \times 68 \mathrm{~m}$, defined by the International Football Federation (FIFA), have been made obligatory for the newly erected facilities.

Two rectangular areas are marked out on the pitch in front of each goal - the penalty area with the dimensions of $16.50 \times 40.32 \mathrm{~m}$ and the goal area of $5.50 \times 18.32 \mathrm{~m}$ (Fig. 1).

Using the principle of double symmetry, our deliberations can be performed on one half of the pitch, or even on its quarter, without losing anything of the general character of the task analysis. Based on the principle of symmetry relative to the half-way line, we shall focus on the lower half of the pitch illustrated in Figure 1. We shall place the $X$ axis of the coordinate system on the goal line, and the origin of the system in the middle of the goal. The $Y$ axis shall coincide with the longitudinal axis of the pitch symmetry. In this system, the coordinates of the left and right goalposts are as follows: $L(-3,66 ; 0), P(+3,66 ; 0)$. The left and right goalposts define the base of the goal $(7.32 \mathrm{~m})$, which is a rectangle that belongs to the vertical plane, with the height of $2.44 \mathrm{~m}$.

The basic aim of playing football is to gain the field of the opposing team and maintain control of the ball until, being close to the goal, the player of the attacking team makes a decision to shoot. In our deliberations, we shall not focus on the complex process of field gain, but we shall consider the relationship between the shooting position and the target itself, which is defending the team's goal. The subject of our considerations is not the tactics of the game, but the spatial relation between the shooting point $S$ and the goal $b=L P$ (Fig. 2).

The analyses shall be limited to the area no larger than half of the pitch, as the shots taken from the other half are completely ineffective and usually end up in losing control of the ball. From a practical point of view, long-range shots taken from the half-line zone are not

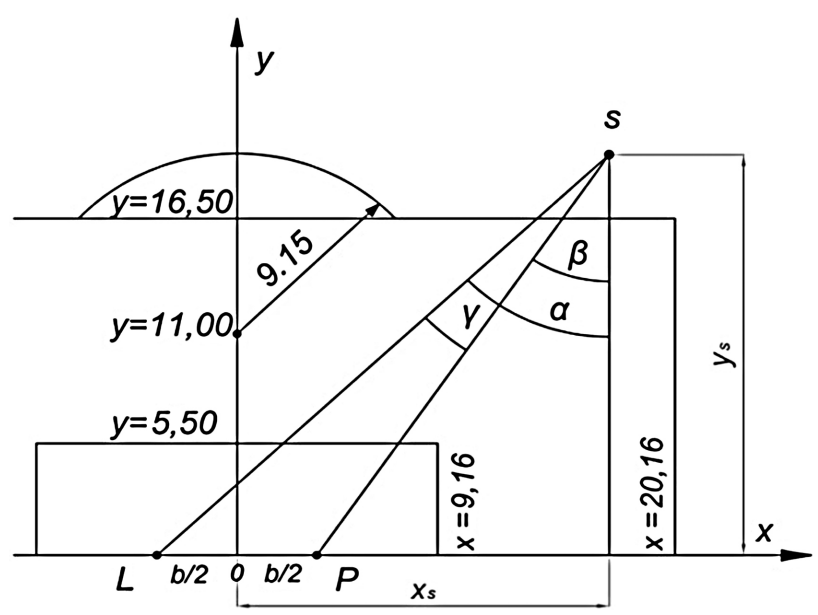

Fig. 2. Spatial relation between the shooting position $S$ and the goal $L P$, geometric illustration of determining the angle $\gamma$ at which the projection of the goal $b=L P$ can be seen from the point $S$

Rys. 2. Relacja przestrzenna pozycji strzału $S$ i bramki $L P$, ilustracja geometryczna wyznaczenia kąta $\gamma$, pod jakim widać rzut światła bramki $b=L P$ z punktu $S$

very effective either, but let us also consider such cases to compare the geometric analyses with the commonly adopted practice.

\section{THE HORIZONTAL ANGLE AT WHICH THE PROJECTION OF THE GOAL CAN BE SEEN FROM ANY POSITION OF THE FIELD OF PLAY}

A shot on goal is not a totally deterministic process it is random to some extent. This means that although the football has been carefully directed, its trajectory will assume a direction that falls within a certain dispersion zone. On the horizontal plane, this zone has the shape of a svelte triangle, whose opening of the sides increases with the increasing distance to the goal. Due to the occurrence of that dispersion zone, shots taken from further distances may be inaccurate. Therefore, from a practical point of view, it is highly recommended that the angle $\gamma$ at which the goal $L P=b$ can be seen from point $S$ (Fig. 2) is much larger than the angle of the dispersion triangle at the node $S$.

Our intuition tells us that the size of the horizontal angle $\gamma$ in the central part of the pitch depends entirely on the distance to the goal and increases very rapidly in 


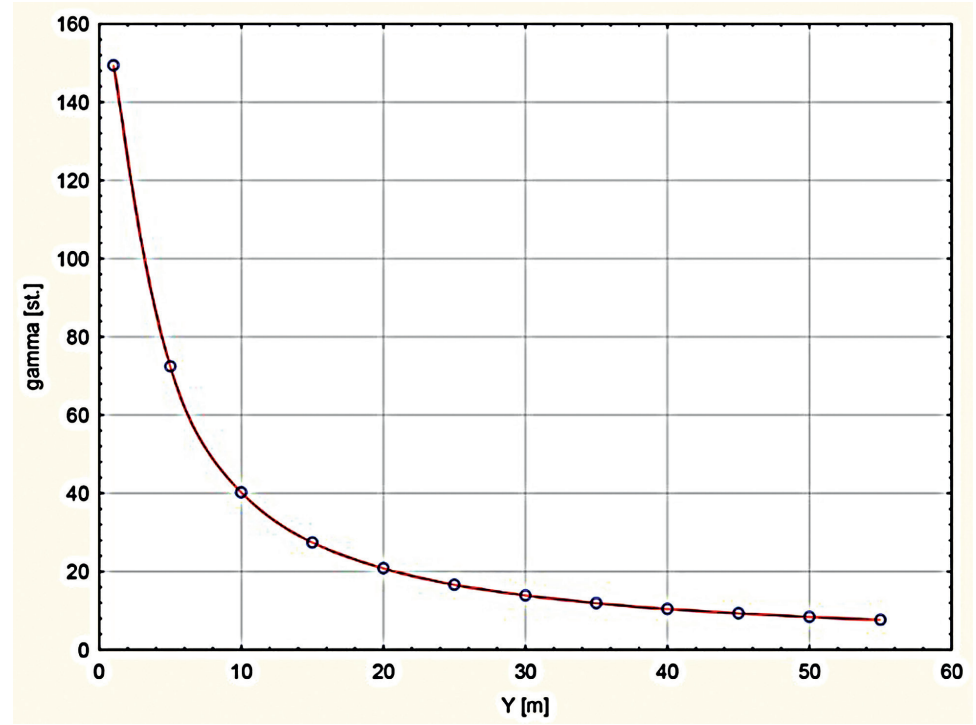

Fig. 3. Graph of the values of the horizontal angle $\gamma$ at which the goal with dimensions $b=7.32 \mathrm{~m}$ can be seen from the points located on the longitudinal axis of the pitch within the range from 1 to $55 \mathrm{~m}$ from the goal. The course of the graph demonstrates a significant decrease in the value of the angle $\gamma$ from the point at a distance of $1 \mathrm{~m}$ from the goal to approximately the penalty mark. Source: own study in Statistica software package

Rys. 3. Wykres wartości kąta poziomego $\gamma$, pod jakim widać bramkę o wymiarach $b=7,32 \mathrm{~m}$ z punktów położonych na podłużnej osi boiska w przedziale od 1 do $55 \mathrm{~m}$ od światła bramki. Przebieg wykresu wskazuje na znaczny spadek wartości kąta $\gamma$ od punktu w odległości $1 \mathrm{~m}$ od bramki w przybliżeniu do punktu rzutu karnego

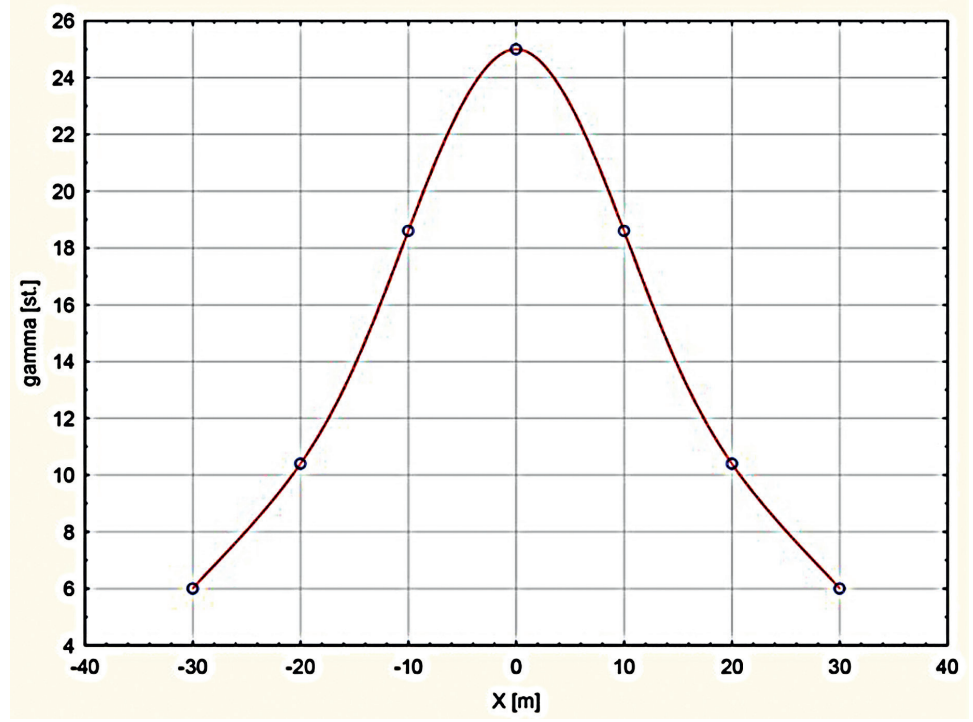

Fig. 4. Graph of the values of the angle $\gamma$ at which the goal can be seen from the points located on the penalty area line, distanced from the goal by $16.5 \mathrm{~m}$. The horizontal scale determines the distances from the longitudinal axis of the pitch to the left and right. The graph illustrates significant decreases in the value of the angle $\gamma$ when the positions of point $S$ are moved by successive intervals towards the touch lines of the pitch. Source: own study in Statistica software package

Rys. 4. Wykres wartości kąta $\gamma$, pod jakim widać bramkę z punktów położonych na linii pola karnego, oddalonej od bramki o 16,5 m. Skala pozioma wyznacza odległości od podłużnej osi boiska w lewo i w prawo. Wykres pokazuje znaczne spadki wartości kąta $\gamma$, gdy pozycje punku $S$ przesuwają się o kolejne interwały ku bocznym liniom boiska 
the vicinity of the goal. When moving away from the longitudinal axis of the pitch towards the wings, the angle $\gamma$ decreases significantly and it should further decrease in this zone as the goal line is being approached.

These intuitive observations have been fully supported by the results of the calculations. Let us begin with the linear analyses along the longitudinal axis of the pitch and on the penalty area line. The results of the calculations have been presented in the form of diagrams in Figures 3 and 4.

Figure 3 illustrates the graph of the values of the angle $\gamma$ on the longitudinal axis of the pitch, depending on the distance from the goal, in intervals of $5 \mathrm{~m}$, from $1 \mathrm{~m}$ to $55 \mathrm{~m}$ from the goal. This is a graph of the angle at which the line segment $b=7.32 \mathrm{~m}$ can be seen, interpolated based on the points at the distance equal to the multiple of $5 \mathrm{~m}$ from the line segment $b$. The graph illustrates a rapid decrease in the value of the angle $\gamma$ within the range of $1 \mathrm{~m}$ to approximately $10 \mathrm{~m}$.

Figure 4 illustrates the graph of the values of the angle $\gamma$ on the penalty area line distant from the goal line by $16.5 \mathrm{~m}$, for the shooting positions moving away from the longitudinal axis of the pitch towards the wings. For the point located on the axis of the pitch, the angle $\gamma$ is equal to $25.0^{\circ}$ and when moving away from this axis by $10 \mathrm{~m}, 20 \mathrm{~m}$ and $30 \mathrm{~m}$, it decreases significantly to the value of $6.0^{\circ}$.

Figure 2 illustrates the method of determining the angle $\gamma$ at which the line segment $L P=b$ can be seen from any position on the pitch. The angle $\gamma$ is calculated from the difference between the angles $\alpha$ and $\beta$ :

$$
\begin{gathered}
\tan \alpha=\frac{x_{S}-x_{L}}{y_{S}}, \\
\tan \beta=\frac{x_{S}-x_{P}}{y_{S}}, \\
\gamma=\alpha-\beta, \\
\gamma=\operatorname{atan} \frac{x_{S}-x_{L}}{y_{S}}-\operatorname{atan} \frac{x_{S}-x_{P}}{y_{S}}
\end{gathered}
$$

In order to create a plot of the values of the angle $\gamma$ as a function of two variables $F(x, y)$, a grid with the number of nodes incrementing along the $X$ and $Y$ axes every $10 \mathrm{~m}$ has been generated on a quarter of the pitch (Fig. 5). Additionally, making use of the principle of symmetry in relation to the longitudinal axis of the pitch, the grid has been located in the first quadrant of the coordinate system, in the zone of positive co-ordinates $x$ and $y$. In order to avoid indeterminate values, the grid lines incrementing along the $Y$ axis start from the value of one metre and consistently demonstrate the subsequent coordinates on the $Y$ axis equalling $11 \mathrm{~m}, 21$ $\mathrm{m}$, up to the value of $51 \mathrm{~m}$. The last grid line is close to the half-way line of the pitch $(y=52.5 \mathrm{~m})$. In Figure 5, the values of the horizontal angle $\gamma$ have been marked black at the nodes of the grid. Between the grid lines, the values of the angle $\gamma$ for the line of the penalty area

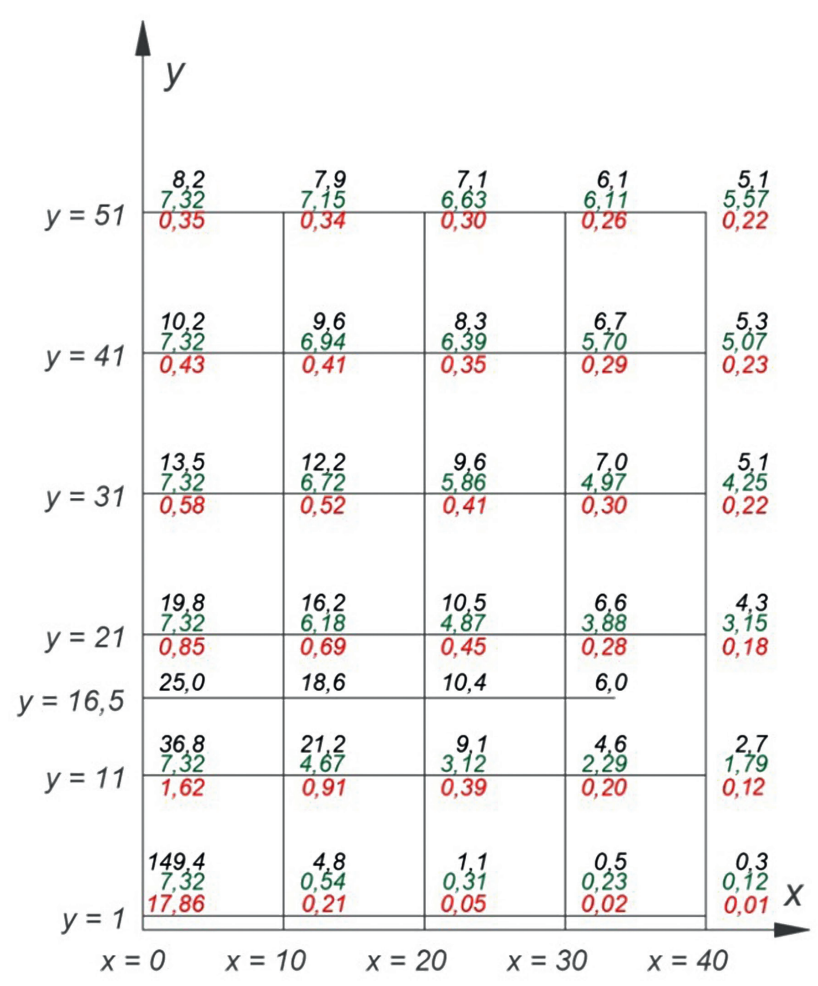

Fig. 5. The principle of double symmetry of the pitch allows us to conduct analyses on its fourth part without any loss to the general character of the considerations. The test grid, covering a quarter of the pitch, contains the values of the angle $\gamma$ marked in black at the nodes with specified coordinates. Other indices have also been noted at the same nodes; they will be discussed later in Chapters 3 and 4

Rys. 5. Zasada podwójnej symetrii boiska umożliwia prowadzenie analiz na jego czwartej części, przy czym nie traci się nic z ogólnego charakteru rozważań. Siatka testowa, obejmująca czwartą część boiska, zawiera wartości kąta $\gamma$ wypisane kolorem czarnym przy węzłach o określonych współrzędnych. Przy tychże węzłach zostały wypisane także inne wskaźniki, które będą omówione w dalszej części rozważań, w punktach 3 i 4 

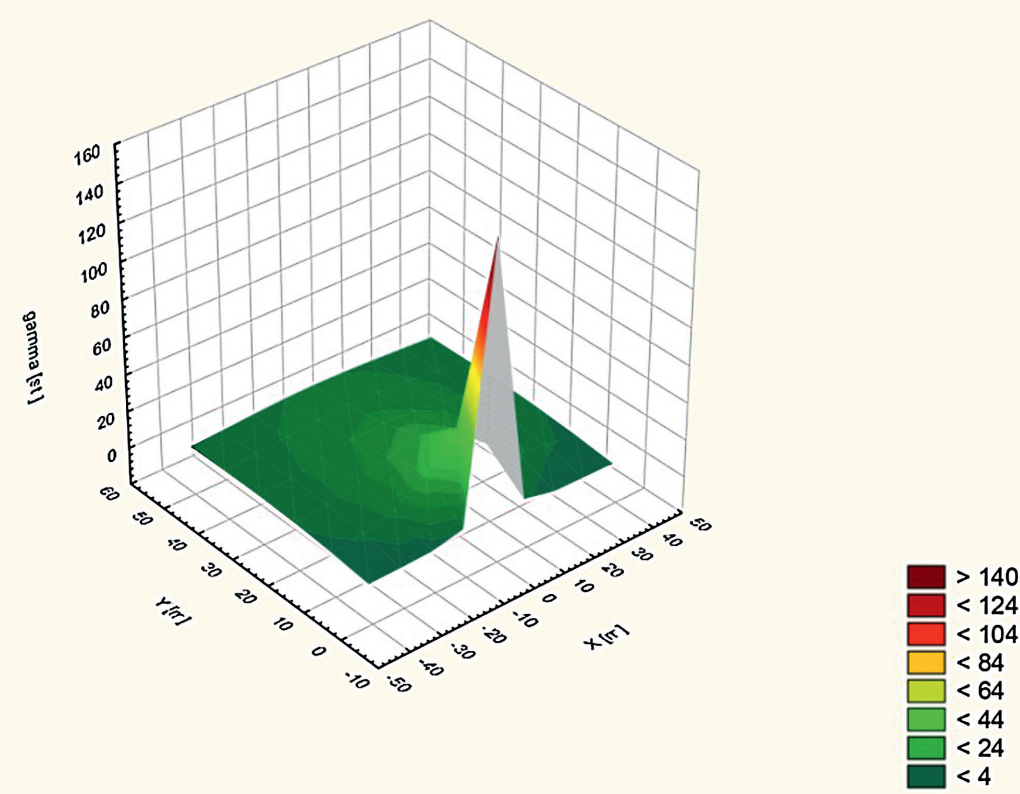

a)

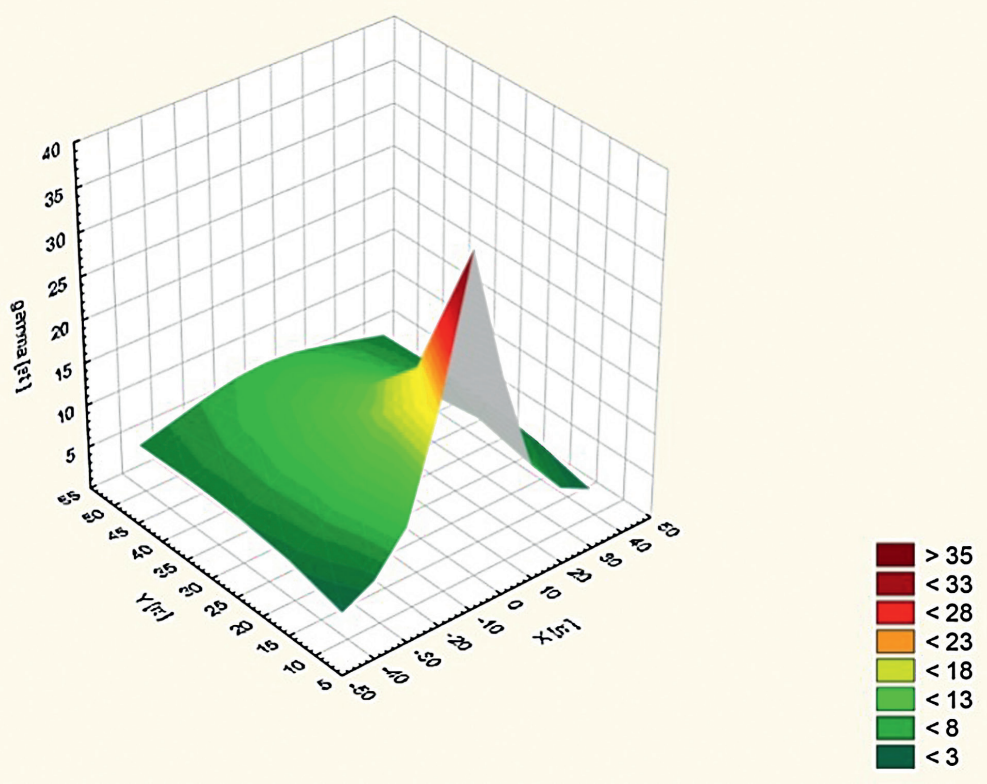

b)

Fig. 6. Surfaces illustrating the distribution of the values of the horizontal angle $\gamma$ at which the goal can be seen from any points of the half of the pitch. In both cases (Fig. $6 \mathrm{a}$ and $6 \mathrm{~b}$ ), there is a visible increase in the value of the angle $\gamma$ in the immediate vicinity of the goal. The construction of the surface on the complete set of the values of the angle $\gamma$ presented in Figure 5 almost completely flattens the surface of a significant part of the analysed area (Fig. 6a). Therefore, to offer better vividness, the values in the nodes distant from the goal line by 1 metre have been neglected (Fig. 6b). Source: authors' own study in Statistica software package

Rys. 6. Powierzchnie przedstawiające rozkład wartości kąta $\gamma$, pod jakim widać światło bramki z dowolnych punktów połowy boiska. W obydwu przypadkach (rys. 6a i 6b) jest widoczne zdecydowane narastanie wartości kąta $\gamma$ w strefie bezpośredniego sąsiedztwa bramki. Zbudowanie powierzchni na kompletnym zbiorze wartości kąta $\gamma$, wykazanych na rysunku 5, prawie całkowicie spłaszcza powierzchnię na znacznej części analizowanego obszaru (rys. 6a). Dlatego dla nadania większej plastyki zostały pominięte wartości w węzłach odległych od linii bramkowej o 1 metr (rys. 6b) 
$(16.5 \mathrm{~m})$ have also been marked. They have been used to prepare the graph in Figure 4.

The values of the angle $\gamma$ calculated from Formula (1) and illustrated in Figure 5 have been used to prepare 3D plots presented in Figures $6 \mathrm{a}$ and $6 \mathrm{~b}$. Figure $6 \mathrm{a}$ demonstrates the surface created from the full number of the grid nodes. The plot reveals a significant difference between the highest value of the angle $\gamma=149.4^{\circ}$ at a distance of one metre from the goal, compared to the other grid nodes. The angle decreases rapidly with the increase of the vertical and horizontal distances from the goal.

The linear vertical scale of the plot results in the nearly complete flattening of its shape on the prevailing area of the grid and fails to demonstrate any variation in the values if such a large dominant value is included. For a better vividness of the plot for a large area of the grid, the values for the line $y=1 \mathrm{~m}$ have not been taken into account in plot $6 \mathrm{~b}$. In this case, the dominant value of the angle $\gamma$ equal to $36.8^{\circ}$ for the penalty spot $(y=11 \mathrm{~m})$ does not flatten the very small values of the angle $\gamma$ over a large area. Plot $6 \mathrm{~b}$ also illustrates the effect of the angle $\gamma$ incrementing on the axis of the pitch as the goal is being approached. The effect of the decreasing value of this angle in the wide areas of the pitch is noticeable as well. The effect of a further decrease in the value of the angle $\gamma$ as it approaches the goal line along the wings is also noticeable, but to a small extent only. In this case, the goal segment $L P=b$ is seen at an increasingly smaller angle, which reaches the value of zero on the goal line of the pitch.

\section{GEOMETRY OF THE DIMINISHED VIEW OF THE GOAL FOR A SHOOTING POSITION THAT DEVIATES FROM THE LONGITUDINAL AXIS OF THE PITCH}

The previous considerations have dealt only with the variable value of the angle $\gamma$ for different positions of the point $S$ on the pitch. It should be noted, however, that any reduction in the value of the angle $\gamma$, beyond the longitudinal axis of the pitch, creates a favourable situation for the team defending their goal: taking a shot from the wide areas of the pitch diminishes the view of the goal. The goal line $L P$ is reduced to the line segment $R P=t$, which is perpendicular to the bisector $S Q$ of the angle $\gamma$ (Fig. 7).

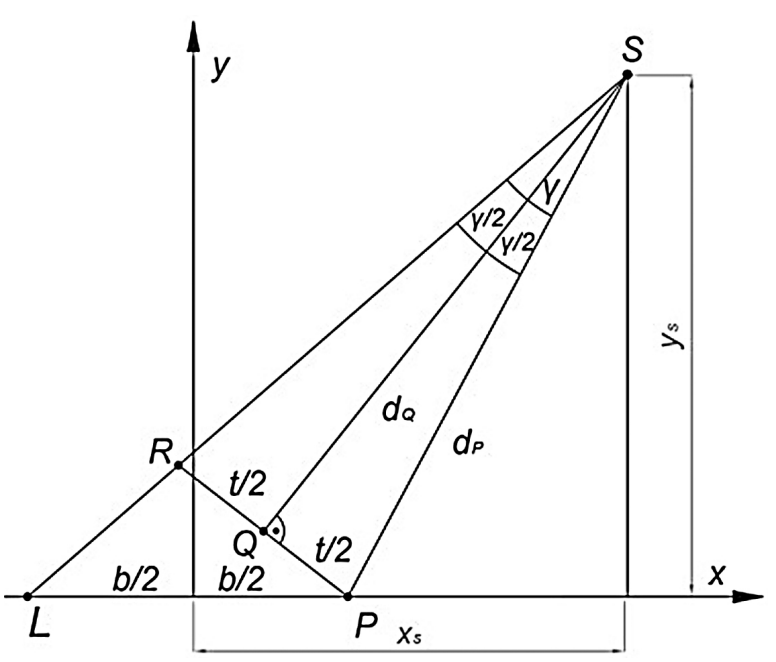

Fig. 7. Graphic illustration of the decreasing projection of the goal $R P=t$ in relation to the nominal dimension $b$ for the shooting position at the goal from the side zones of the pitch Rys. 7. Ilustracja graficzna zmniejszającego się rzutu światła bramki $R P=t$ w relacji do nominalnego wymiaru $b-$ dla pozycji strzału do bramki ze stref bocznych boiska

Let us analyse the length of the line segment $t$ depending on the position of the point $S$ relative to the goal $L P$. From the right triangle determined by the abscissa and the ordinate of the point $S$, we can calculate the distance $d_{P}$ of the point $S$ to the nearer goalpost $P$ :

$$
d_{P}=\sqrt{\left(x_{S}-x_{P}\right)^{2}+y_{S}^{2}}
$$

Having substituted the real value of $3.66 \mathrm{~m}$ (half of the actual goal dimension of $7.32 \mathrm{~m}$ ) for $x_{P}$, and having squared the coordinate difference, the following Formula for the length of the line segment $d_{P}$ is obtained:

$$
d_{P}=\sqrt{x_{S}{ }^{2}+y_{S}^{2}-7,32 x_{S}+13,40}
$$

From the right triangle $S P Q$, half of the line segment $t$ is calculated:

$$
\frac{t}{2}=d_{P} \cdot \sin \frac{\gamma}{2}
$$

By substituting Formula (3) for $d_{P}$, the length of the line segment $t$ can be calculated from the final Formula:

$$
t=2 \cdot \sin \frac{\gamma}{2} \cdot \sqrt{x_{S}^{2}+y_{S}^{2}-7,32 x_{S}+13,40}
$$

Figure 5 presents the values of the line segment $t$ for the conventional grid nodes, which have been marked 


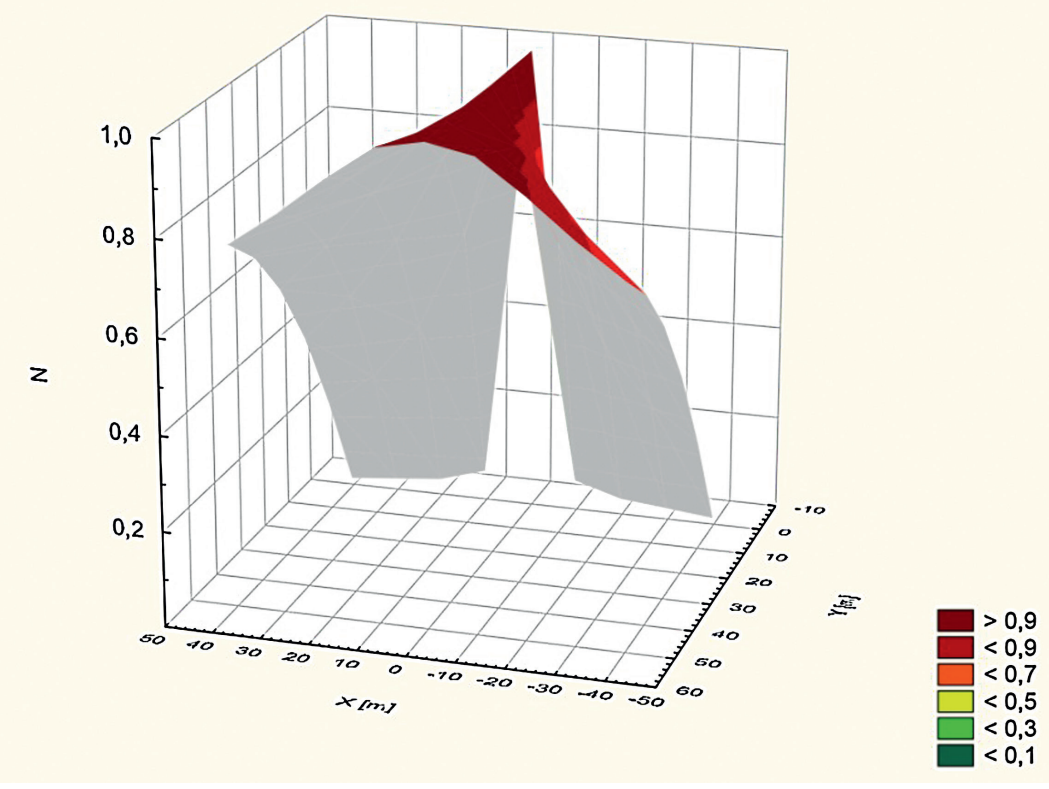

a)

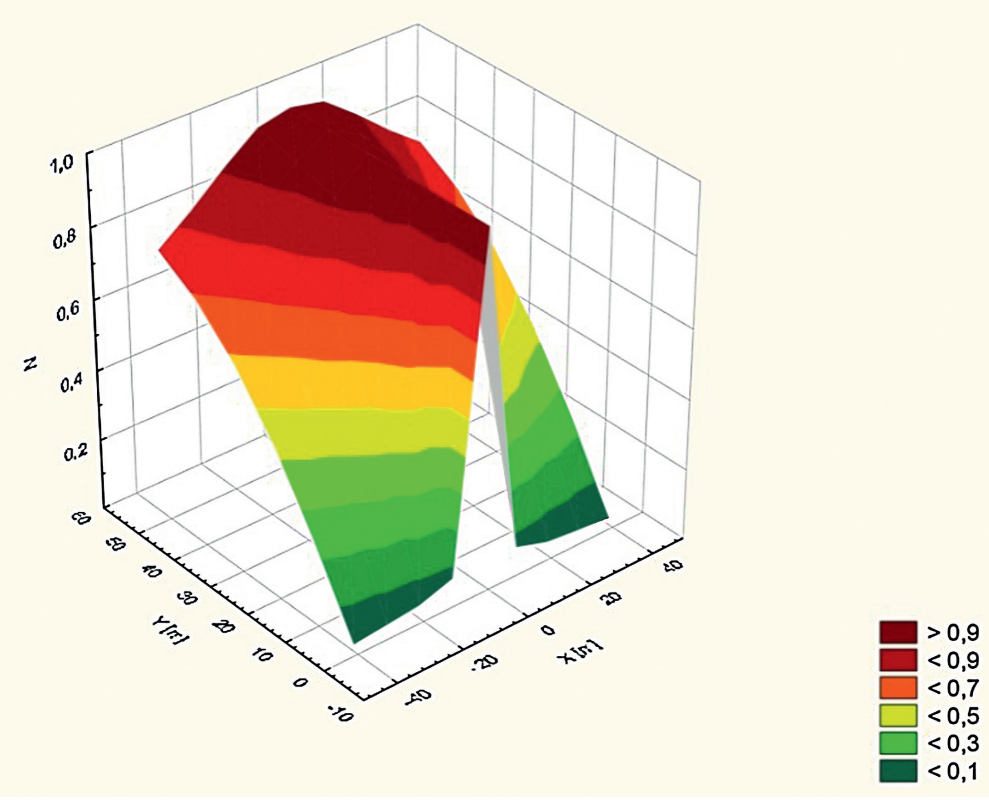

b)

Fig. 8. Surfaces depicting distribution of the values of the $N$ indicator, which is the quotient of the local value of the projection of the goal $t$ and its nominal value $b$. Figure 8a (view from the inside of the pitch) illustrates a rapid decrease in the value of the $N$ indicator as the goal line is approached along the side zones of the pitch. Figure $8 \mathrm{~b}$ (view from the outside of the pitch, beyond the goal line) confirms this observation. Both plots depict invariability of the $N$ indicator (at its maximal value of 1.0) for the points located on the longitudinal axis of the pitch. Source: own study in Statistica software package

Rys. 8. Powierzchnie przedstawiające rozkład wartości wskaźnika $N$, stanowiącego iloraz lokalnej wartości rzutu światła bramki $t$ do wartości nominalnej $b$. Rysunek 8a (widok od strony wnętrza boiska) wskazuje na szybkie zmniejszanie się wskaźnika $N$ w miarę zbliżania się do linii bramkowej boiska w jego strefach bocznych. Rysunek $8 \mathrm{~b}$ (widok od strony zewnętrznej boiska, spoza linii końcowej) potwierdza to spostrzeżenie. Obydwa wykresy wykazują niezmienność wskaźnika $N$ (na poziomie maksymalnej wartości 1,0) dla punktów zlokalizowanych na podłużnej osi boiska 
in green. Obviously, for the nodes located on the longitudinal axis of the pitch, the view of the goal is not diminished, and for all these nodes the line segment $t$ corresponds to the nominal value of the projection of the goal, i.e. $7.32 \mathrm{~m}$.

To illustrate the diminished view of the goal in an illustrative manner, the $N$ indicator has been calculat$\mathrm{ed}$, which is the quotient of the local value of $t$ and the nominal value of the projection of the goal $b=7.32 \mathrm{~m}$ :

$$
N=\frac{t}{b}
$$

Based on the values of this indicator, 3D plots of the surfaces have been prepared and depicted in Figures 8a and $8 \mathrm{~b}$.

Figure $8 \mathrm{a}$ presents a view from the inside of the pitch, while Figure $8 b$ depicts a view of the surface from the outside of the pitch, beyond the goal line. In both cases, as the player moves away from the longitudinal axis and towards the wings, a diminishing projection of the goal is clearly noticeable. A significant decrease of the $N$ indicator in the end zones of the pitch, on the side of the defending team, is particularly distinct. In both plots, it is noticeable that the projection of the goal remains at its nominal value on the longitudinal axis of the pitch - the $N$ indicator assumes the maximum value of 1.0 on the entire length of this line.

\section{COMPARABLE, PRACTICAL INDICATOR OF OPPORTUNITY}

So far, we have considered three indicators characterising the relationship between the randomly selected position on pitch $S$ and the goal $L P$ : angle $\gamma$ as the view angle of the goal segment $b$, line segment $t$ representing the projection of the goal when the point $S$ is not on the longitudinal axis of the pitch, $N$ indicator as the quotient of the local value of the line segment $t$ and the nominal dimension of the goal $b=7.32 \mathrm{~m}$. The above-mentioned indicators have allowed a demonstrative presentation of their values in the form of $3 \mathrm{D}$ plots.

Let us try, however, to formulate a practical indicator corresponding to everyday experience, which would be illustrative not only in a graphic form, but also as a numerical value.

We can easily imagine a relationship between a real-size aiming target and a distance to this target. In football, such an "aiming target" is the goal, which has a horizontal dimension $b=7.32 \mathrm{~m}$ and a height $h=2.44 \mathrm{~m}$. Thus, the actual area of the target is $17.86 \mathrm{~m}^{2}$. Taking into account the decreased projection of the goal $b$ (for the shots taken from more or less acute angles) relative to the value of $t$, analysed in Chapter 3 - let us proceed from the projections to the real surface dimensions and build the surface $T$ on the line segment of the projection $t$ :

$$
T=t h
$$

With the goal presented in the real form, we can additionally calculate the distance at which this "aiming target" is set. This distance has been marked as $d_{Q}$ in Figure 7. It runs along the angle $\gamma$ bisector and is perpendicular to the line segment $t$. The distance $d_{Q}$ can be calculated from the triangle $S P Q$ :

$$
d_{Q}=d_{P} \cdot \cos \frac{\gamma}{2}
$$

With the general form of the aiming area of the goal (7) and the distance to it (8), we can formulate a practical indicator of opportunity $V$ as a quotient of $T$ and $d_{Q}$ :

$$
V=\frac{T}{d_{Q}}=\frac{t \cdot h}{d_{P} \cdot \cos \frac{\gamma}{2}}=\frac{2 h \cdot d_{P} \sin \frac{\gamma}{2}}{d_{P} \cdot \cos \frac{\gamma}{2}}=2 h \cdot \operatorname{tg} \frac{\gamma}{2}
$$

The $V$ indicator is a proof of the principle of a successful shot taken from any position on the pitch being directly proportional to the aiming area of the goal corresponding to a given position, and inversely proportional to the distance to the goal. The values of the $V$ indicator have been calculated for the grid nodes and noted down in red in Figure 5. Their analyses have confirmed our previous observations. For the farther zone, close to the centre of the pitch, the $V$ indicator assumes a value of approximately 0.3 to 0.4 , for the line in the pitch axis, as the player approaches the goal, it increases to the value of 17.86, while for the deep wings it ranges from 0.1 to 0.2 . For the penalty spot, the indicator is 1.62 , and it takes the value of 1.0 on the pitch axis at a distance of 17.86 metres from the goal, i.e. circa 1.4 metres further away from the penalty box line.

Based on the values of the $V$ indicator, noted down in red at the nodes of the grid in Figure 5, a 3D plot of the surface has been created and presented in Figure 9. Taking from the experience gained while preparing the plot illustrated in Figure 6a, which included large 


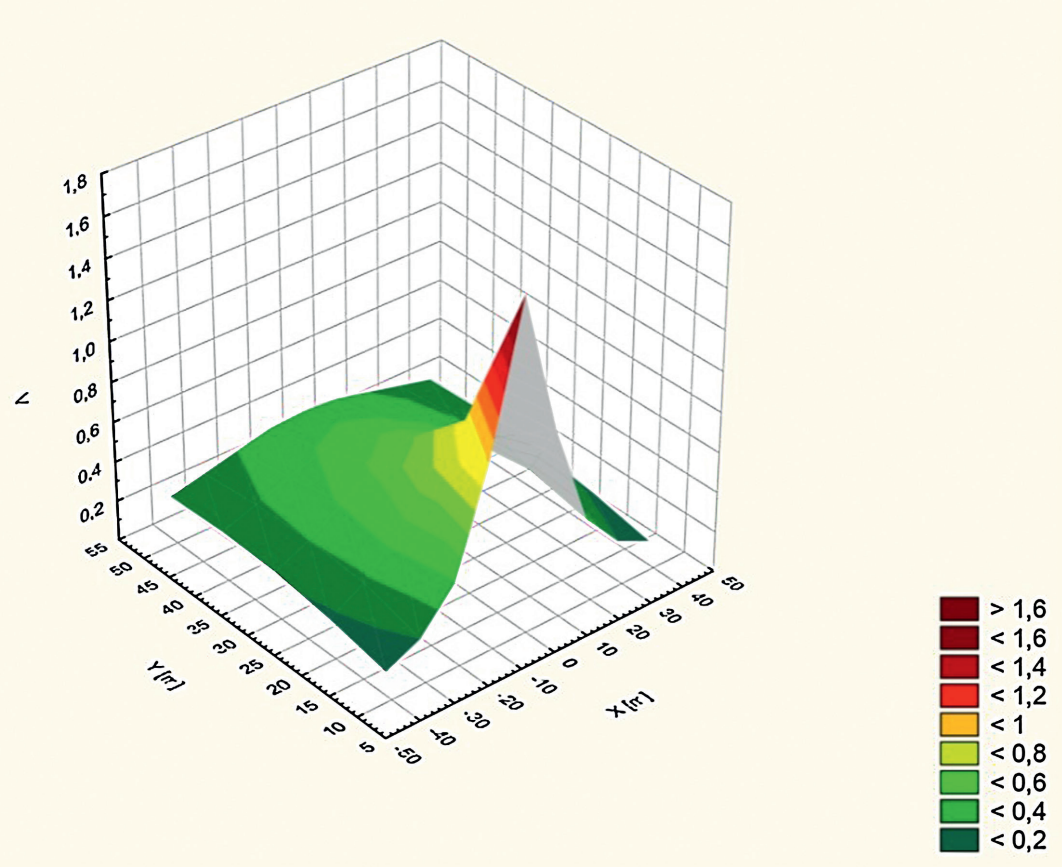

Fig. 9. Surface illustrating the distribution of the $V$ indicator being the quotient of the local dimension of the goal and the distance of the point $S$ to its projection $t$. In order to illustrate vividness of the graph in areas with small values of the indicator, the values in the nodes distant from the goal line by 1 metre have been neglected. Source: own study in Statistica software package Rys. 9. Powierzchnia przedstawiająca rozkład wskaźnika $V$, stanowiącego iloraz lokalnej wielkości światła bramki do odległości punktu $S$ od rzutu $t$ tego światła. Dla pokazania plastyki wykresu w rejonach o niewielkich wartościach wskaźnika, zostały pominięte wartości w węzłach odległych od linii bramkowej o 1 metr

values on the grid line $y=1 \mathrm{~m}$ and thus resulted in its extensive flattening on the prevailing area of the grid, the authors have neglected this line (as in Figure 6b) and used the values starting from the line $y=11 \mathrm{~m}$. This has allowed us to obtain a clear and vivid surface plot (Fig. 9).

There is a distinct characteristic similarity between the plots $6 \mathrm{~b}$ and 9 because they have been created from the values of the angle $\gamma$ and from the tangent of its half, respectively, within the range of the tangent values allowing such similarity. However, in this case, the $V$ indicator is more illustrative and clear in direct evaluation, not only in graphic, but also in numerical form.

\section{EQUAL OPPORTUNITY ISOLINES}

Using the grid presented in Figure 5, we could demonstrate the distribution of the indicators for various positions on the pitch. Finally, let us try to determine equal opportunity isolines for some standard distances from the goal line.
Let us assume three isolines, whose distances $i$ from the goal line in the longitudinal axis of the pitch will be $20 \mathrm{~m}, 15 \mathrm{~m}$ and $10 \mathrm{~m}$. We shall use the principle that an angle inscribed in a circle, based on the same chord, is equal for each point on the circumference of this circle. Therefore, the circles with properly calculated radii, based on the chord of the goal $L P$, will be isolines of the equal values of the angle $\gamma$ for the points $S$ located on the circumferences of these circles.

Our task is to calculate the radii of the circles for the three assumed isolines. The diameters of the isolines are not equal to the distances of the point $S$ to the goal line because the isolines must be based on the chord of the goal LP (Fig. 10). Hence, the distances between the origins of the circles and the goal line are smaller than the radii. In this task (Fig. 10), the dimensions of the chord $L P=b$ and the distances $i$ of the point $S$ to the goal line $(10,15$ and $20 \mathrm{~m})$ are given. We will obtain the radii of the circles by calculating the chord $S P=c$ followed by the height $e$ of the triangle built on this chord. 


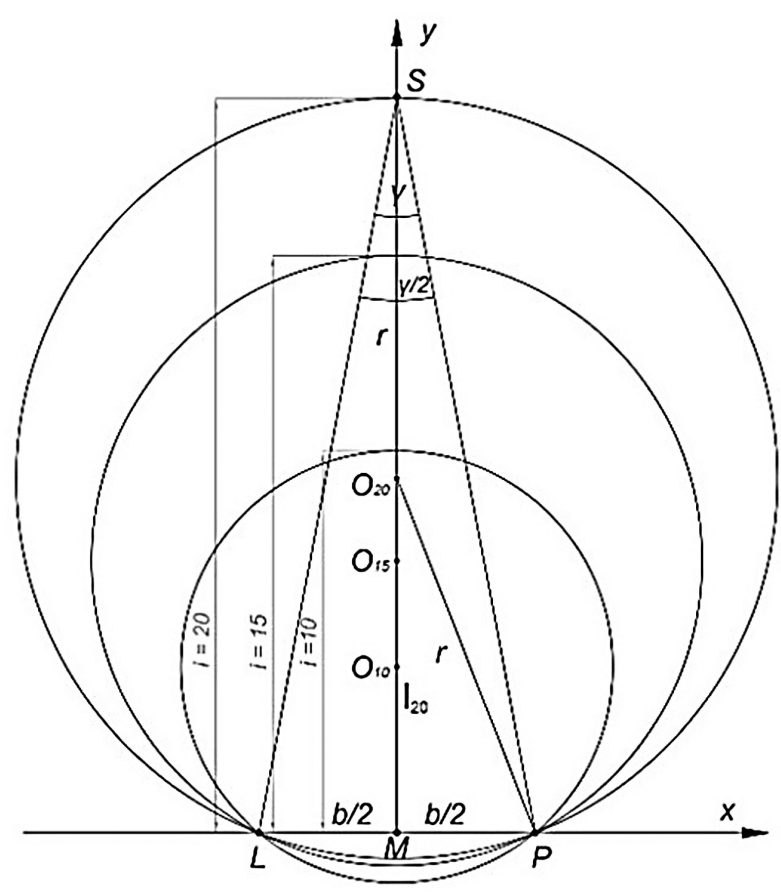

Fig. 10. Equal opportunity isolines taking the shape of circles based on the chord of the goal $L P=b$ for three distances $i$ of the point $S$ (on the longitudinal axis of the pitch) to the goal line: 10,15 and $20 \mathrm{~m}$. The angles $\gamma$ inscribed in circles retain their fixed values for each position of the point $S$ on the circumference of a given circle

Rys. 10. Izolinie równej szansy o kształcie okręgów opartych na cięciwie bramki $L P=b$ dla trzech odległości punktu $S$ (na osi podłużnej boiska) do linii bramkowej: 10, 15 i $20 \mathrm{~m}$. Kąty $\gamma$ wpisane w okręgi zachowują swoje niezmienne wartości dla każdego położenia punktu $S$ na danym okręgu

Therefore, e.g. for the triangle $P O_{20} M$, the following relationship holds:

$$
r^{2}=l_{20}^{2}+\left(\frac{b}{2}\right)^{2}
$$

From the triangle PSM we obtain:

$$
r+l_{20}=i_{20}
$$

Thus:

$r^{2}=\left(i_{20}-r\right)^{2}+\left(\frac{b}{2}\right)^{2}=i_{20}^{2}-2 i_{20} r+r^{2}+\frac{b^{2}}{4}$

Having reduced the like terms and transformed the equation (12), we obtain (for any given distance $i$ ):

$$
r=\frac{b^{2}+4 i^{2}}{8 i}
$$

The angle $\gamma$ can be calculated from the following dependence:

$$
\gamma=2 \operatorname{arctg} \frac{\frac{b}{2}}{i}
$$

Based on Formulas (13) and (14), the radii of the three equal opportunity isolines as well as the values of the angle $\gamma$ for these isolines have been calculated. The results of these calculations are summarised in Table 1.

Tab. 1. Radii of three exemplary equal opportunity isolines, illustrated in Figure 10

Tab. 1. Promienie trzech przykładowych izolinii równej szansy, przedstawionych na rysunku 10

\begin{tabular}{|c|c|c|}
\hline $\begin{array}{c}\boldsymbol{i} \\
{[\mathbf{m}]}\end{array}$ & $\begin{array}{c}\boldsymbol{r} \\
{[\mathbf{m}]}\end{array}$ & $\begin{array}{c}\boldsymbol{\gamma} \\
{\left[{ }^{\circ}\right]}\end{array}$ \\
\hline 20 & 10,33 & 20,74 \\
\hline 15 & 7,95 & 27,42 \\
\hline 10 & 5,67 & 40,20 \\
\hline
\end{tabular}

The conclusions drawn from the courses of the isolines have confirmed all our observations. Taking the shooting position $S$ near the longitudinal axis of the pitch is especially favourable. In order to be afforded the same opportunity in the wing position, away from this line by the value of the radius $r$, we would have to get closer to the goal by approximately half the original distance, which is associated with the necessity to gain the field in the zone of the concentrated defence of the opposing team. That is why the standard rule of the game is gaining the field along the wings and ultimately passing the ball to the central part of the pitch. Such a pass is called a cross pass.

Finally, it is worth reflecting on the shape that the isolines would take for the $V$ indicator defined in Chapter 4. Let us go back to Figure 7 and Formulas (7) and (9). The $V$ indicator is a doubled tangent of the $\gamma / 2$ angle multiplied by the constant $h$. If, therefore, the isolines are dependent on the angle $\gamma$ based on the chord $L P$, then the isolines for the $V$ indicator will also be circles, because in this case the invariable angle $\gamma$ will be replaced by the invariable double tangent of the $\gamma / 2$ angle, multiplied by the constant $h$. 


\section{SUMMARY AND CONCLUSIONS}

In several team sports, a problem occurs in the relationship between a randomly selected point of the field of play and the target (the goal). However, due to the much larger dimensions of the football pitch, the determined relationships in this discipline may be the most distinct. The subject of the conducted analyses is not the tactics of the field gain, but the assessment of the opportunity to take a direct shot on goal from any position of the pitch.

In every shot on goal there is an element of randomness; it is not a totally deterministic process. Therefore, a decision to desist from the field gain and to take a shot must take into account the relationship between the possible angle of dispersion and the angle at which the goal can be seen. The latter (denoted as $\gamma$ ) is devoted special attention in this article (Fig. 2). The authors have emphasised its variability on the longitudinal axis of the pitch (Fig. 3) and its significant decrease as the player moves away from this axis towards the wings, or the touchlines of the pitch (Figs 4, 5 and 6).

In the later part of this research paper, we have paid special attention to the fact that the view of the goal decreases as the player moves away from the longitudinal axis of the pitch (Fig. 7). By turning the direction of the goal line $b$ to the direction that is perpendicular to the line of shot, we obtain a decreased projection of the goal $t$. This is a phenomenon of the inverse increment of the angle at which the goal can be seen: this angle increases significantly as the player approaches the goal area along the longitudinal axis, whereas approaching the end line of the pitch along the wings results in a gradual decrease of the angle $\gamma$ (Figs 5 and 6b). Therefore, gaining field along the deep wings and, consequently, approaching the goal area, worsens the opportunity of a direct shot on goal, but is undoubtedly favourable for the tactics of the play.

The indicators such as angle $\gamma$, decreased projection of the goal $t$ and its quotient version $N$ - aptly define various spatial situations that occur in the field of play. However, in order to add better illustration to the assessment, another indicator $(V)$ has been proposed, which is reflecting everyday experience. It treats the changing view of the goal as an "aiming target" observed from varying distances. For a large part of the pitch half, the value of this indicator is expressed by a numbers less than 1 , and around the middle of the penalty box, it slightly exceeds 1.6.

The similarity between the plots $6 \mathrm{~b}$ and 9 is distinct because they have been created from the values of the angle $\gamma$ and from the tangent of its half, within the range of the tangent function values allowing such similarity. These similar 3D plots are an alternative illustration of the same principle.

The comparability of the opportunities has also been demonstrated in the form of circle-shaped isolines, based on the chord of the goal $L P=b$ (Fig. 10).

All the indicators and performed analyses have confirmed the standard rule and aim of football which involves favourable field gain along the wings and finally crossing the ball into the middle field, as near the opponent's goal as possible, where the chances of scoring are the greatest (Galbraith \& Lockwood, 2010). But it should be noted that this central zone is heavily defended. Therefore, if the ball is carefully directed from the wide areas of the pitch, the opponent's goal can also be threatened, considering that giving the ball a spin makes it follow a curved path (Ernst, 1992). Besides, the current parameters of the balls, their resilience and smoothness of the surface, create favourable physical conditions for effective shots also from further distances.

\section{REFERENCES}

Eckes K. (2012): Geometria piłki. Geodeta - Magazyn Geoinformacyjny, Warsaw, no. 6 (205), pp. 8-11.

Eckes K. (2018): Czy piłkarze stosują geometrię?. Geodeta Magazyn Geoinformacyjny, Warsaw, no. 7(278), pp. 48-53.

Ernst K. (1992): Fizyka sportu. Wydawnictwo Naukowe PWN, Warsaw.

Galbraith P., Lockwood T. (2010): Things may not always be as they seem: the set shot in AFL Football. Australian Senior Mathematics Journal, vol. 24 no. 2, , pp. 29-42. 